Canadian

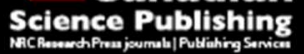

Canadian Journal of Civil Engineering Revue canadienne de génie civil

\title{
Life Cycle Assessment of Low-Rise Office Building with Different Structure-Envelope Configurations
}

\begin{tabular}{|r|l|}
\hline Journal: & Canadian Journal of Civil Engineering \\
\hline Manuscript ID & cjce-2015-0431.R1 \\
\hline Manuscript Type: & Article \\
\hline Date Submitted by the Author: & 14-Oct-2015 \\
\hline Complete List of Authors: & $\begin{array}{l}\text { Alshamrani, Othman; College of Architecture and Planning, University of } \\
\text { Dammam, Building Engineering }\end{array}$ \\
\hline Keyword: & Energy Simulation, LCA, Structure and Envelope, Environmental Impact \\
\hline \multicolumn{2}{|c}{} \\
\hline
\end{tabular}

\section{SCHOLARONE ${ }^{m}$}

Manuscripts 


\title{
Life Cycle Assessment of Low-Rise Office Building with Different Structure-Envelope Configurations
}

\author{
Othman Subhi Alshamrani \\ Department of Building Engineering,, College of Architecture and Planning, \\ University of Dammam, Dammam, Saudi Arabia \\ Email: osalshamrani@uod.edu.sa \\ Phone: +966 548008002
}

\begin{abstract}
This paper presents life cycle assessment (LCA) approach to study the impact of structure and envelope types on the energy consumption and environmental impact of an office building in the New York City of USA. In addition, the future costs of environmental impact for various structure and envelope options are assessed according to the current practice and market price of $\mathrm{CO}_{2}$. Eight structure and envelope types for the low-rise office building are investigated, which include concrete and steel structures with various combinations of envelopes. The parameters such as life cycle energy use, global warming potential, and water, air and land emissions are analyzed. The energy simulation is performed by using eQUEST software while the environmental impact is assessed by using ATHENA ${ }^{\circledR}$ impact estimator. The building with concrete frame is proved to have lower environmental impact compared to that with steel frame. The precast concrete building is found to be the economical alternative due to the minimal environmental impact cost. This study is expected to enable the decision makers and building
\end{abstract}


owners select the best alternative with respect to energy use, and environmental and economic constraints.

Keywords: Energy Simulation; LCA; Structure and Envelope; Environmental Impact; Energy Consumption; Global Warming.

\section{Introduction}

The building sector has a significant role on energy resource depletion and environmental pollution. A building has direct and indirect consumptions of energy. Direct consumption is for construction, operation, renovation and demolition while indirect energy indicates that used for the production of construction material and technical installations (Sharma et al. 2011). The environmental impact is mainly due to the greenhouse gas and other harmful emissions associated with each lifecycle stages of a building. According to the latest reports of United Sates (US)' Department of Energy, buildings account for $40.2 \%$ of the primary energy consumption of US (DOE 2015). Thus, the significant potential of building sector in reducing energy consumption as well as environmental impact is quite obvious. Nevertheless, the ongoing scientific challenge is to apply a cradle-to-grave approach for the realistic and accurate assessment of these parameters. The Life Cycle Assessment (LCA) technique has been popular in the last decade, owing to its comprehensive and systemic approach to environmental evaluation. The reviews by Ramesh et al. (2010), Ortiz et al. (2009), Sharma et al. (2011), Khasreen et al. (2009) and Cabeza et al. (2014) provide detailed insight into the various LCA practices in buildings, while Cole (1998) outlined the emerging trends in building environmental 
assessment methods. However, a review of few works that help build a background to the current study is presented as follows.

Zhang et al. (2006) developed a building environmental performance analysis system based on the LCA framework, which could assess three main aspects of a building such as facilities, materials and location. Liu et al. (2010) proposed an exergy assessment model for the environmental impact of the building lifecycle by considering energy consumption, resource consumption and pollutant discharge with reference to energy-embodied exergy, resource chemical exergy and abatement exergy, respectively. This model was applied on a building in Chongqing (China) and found that the energy consumption constituted $70-80 \%$ of the total environmental impact during a 50-year building lifecycle, in which the operation phase accounted for $80 \%$ of the total environmental impact, while $15 \%$ for the building material production phase and $5 \%$ for the other phases.

A study by Mora et al. (2011) incorporated life-cycle considerations in the design process to enable selection of materials and systems not only from environment-friendly resources but also to match service life performance expectations. Collinge et al. (2013) attempted to integrate indoor environmental quality into LCA, to study chemical-specific and non-chemical health impacts, and productivity/performance impacts. They showed that for human health respiratory effects, building-specific indoor impacts were $12 \%$ of global external impacts in conventional LCA. Building-specific indoor cancer toxicity impacts were greater while non-cancer toxicity impacts were lower, compared to external impacts. This study demonstrated the importance of treatment of mechanically supplied outdoor or recirculated indoor air, as well as control of pollution from indoor sources such as building materials or cleaning products. Thormark (2000) 
studied the impact of recycling potential of building materials after demolition on the energy savings in a single family house, and found that the recycling has significant potential to reduce the energy consumption and environmental impact of buildings.

Grant and Ries (2012) have developed a model that incorporated service life, operational energy and LCA, to study the effects of materials and systems in building operation, maintenance, repair and replacement. Hernandez and Kenny (2010) presented a methodology to integrate life cycle energy analysis (LCEA) and comfort expectations with building energy evaluation. The method was demonstrated in an Irish building, and it was concluded that the differences in occupants expected temperature and ventilation levels could be important issues to consider when selecting heating and ventilation systems for minimum life cycle energy use. An integrated performance model (IPM) was developed by Iwaro et al. (2014 a \& b), as a tool to aid the sustainable design of residential building envelope, and reduce the energy consumption and carbon emission. The IPM application has revealed that the life cycle energy efficiency was the most decisive criterion for the sustainability score of the building. The significance of LCA in the sustainability assessment was also demonstrated by Alshamrani et al. (2014) (the author's previous work), which proposed an integrated LCA-LEED model for sustainability of Canadian school buildings.

Similar studies on various types of buildings from different countries have also been reported, which include the LCA approach developed and demonstrated in the strategic design of a flagship store in Shanghai, a multi-criteria evaluation comparing factory-built wood-frame exterior walls for a Canadian residential building, an AHP-based study for the selection of sustainable flooring system in Tehran, an input-output hybrid LCA approach for US's commercial buildings, a study on an Italian low-energy consumption building, and the LCEA 
models proposed for Australian school and residential buildings, the dynamic LCA (DLCA) approach proposed for a building at the University of Pittsburgh, a multi-criteria decision making model for the sustainability assessment of concrete columns of medium-sized residential buildings in Spain, the integrated LCC (life cycle cost)-LCA sustainability assessment model developed in Germany (Wang et al. 2010; Frenette et al. 2010; Reza et al. 2011; Onat et al. 2014; Proietti et al. 2013; Ding 2007; Treloar et al. 2000; Collinge et al. 2013; Pons and De La Fuente 2013; König and De Cristofaro 2012), and so on.

Office buildings are significant energy consumers and source of emissions in industrialized countries(Junnila et al. 2006). One of the pioneering studies on office buildings was reported by Cole and Kernan (1996) who focused on 3-storey office building to assess the life cycle energy use with alternative wood, steel and concrete structural systems. The operating energy was found to be the largest component of life-cycle energy use. Junnila et al. (2006) performed LCA of newly constructed European and U.S. office buildings, and indicated the dominance of operating phase in the quantified environmental categories. By quantifying the energy use and environmental emissions of each life-cycle phase in more detail, the elements that caused significant emissions could be identified and targeted for improvement. A life-cycle inventory model for office buildings was developed by Xing et al. (2008), who compared the environmental effects of steel and concrete structures. For the whole life-cycle, the concreteframed building was found to be attractive when compared to the other, in terms of energy consumption and environmental impact of building materials. However, there is significant scope for LCA analysis for effective assessment of energy consumption and environmental impact by considering various structure-envelope configurations. Accordingly, this study presents an LCA-based analysis of a low-rise office building at New York City, to explore the 
effect of structure and envelope on the energy consumption and environmental impact. The environmental parameters such as are analyzed. The environmental impact is assessed by using ATHENA ${ }^{\circledR}$ software, which analyses energy consumption, global warming potential, and air, water and land emissions.

\section{Methodology}

The overall methodology of the current study is illustrated in Figure 1, which shows the various inputs, processes and the expected outputs. Concrete and steel structural frames as well as envelope systems such as precast panels, steel siding on steel stud, aluminum cladding, double glazing or (Curtain walls) and cavity wall constituted the eight tested alternatives, as shown in Table1. The process includes energy simulations and the assessment of LCA components such as energy consumption, global warming potential, and water, land and air emissions. Figure 2 displays the detailed sections for some of the various tested alternatives. The energy performances of the various envelope systems are measured by performing hourly energy simulations to calculate the monthly electricity and natural gas consumptions. The energy simulation is done by using the eQUEST ${ }^{\circledR}$ software, which is a product of United States' department of energy (DOE) and is commonly used in North America. This tool is based on identifying some normalized and variable parameters that affect the energy consumption of the office building under study. Figure 3 shows the physical model for the office building in the New York City, which is used for energy simulation as well as to assess the environmental impact associated with the different structure-envelope combinations. The life cycle stages included manufacturing, construction, maintenance, operation and end-of-life. 
Figure 1: The proposed environmental impact assessment model.

Table1: Tested Structure-Envelope configurations with floor and roof types.

Figure 2: Detailed sections for structure-envelope options such as CC, CM, SC and SS.

The impact estimator software used to perform this study is ATHENA $^{\circledR}$ 2011, which is developed by Athena Institute Canada, exclusively for North American cities, and is used by most of the practitioners and researchers. This tool incorporates ATHENA's databases, which cover many of the building structure and envelope types. Since environmental impacts are assessed based on the type and bill of materials as indicated in Table 2, the software requires the description of the architecture, structural components, and the annual energy consumption as calculated by the energy simulation software. There are many input parameters and assemblies that are defined into the software, such as footings, slabs on grade, columns and beams, floors, roofs, interior walls, exterior walls, windows, other material such as insulation, fire proofing and water proofing membrane. Eight various structures and exposure systems are investigated considering a life-span of 60 years, over the life cycle stages such as manufacturing, transportation, construction, maintenance, operating, and end-of-life. 
Figure 3: Structural framing plan and 3D perspective for the prototype tested model:

a) Structural plan, b) Perspective view.

Table 3 provides detailed data on the activity areas of the study building and their percentage allocations, and occupied loads. The various other inputs used in the simulation pertaining to the building, wall and roof are summarized in Table 4 and Table 5 . The office functions 5 days per week from 8 a.m. to 5 p.m., and the occupancy, and lighting and equipment loads are assumed as $90 \%$. The air-conditioning system is assumed to operate $1 \mathrm{~h}$ before and after the working hours.

Table 2: Bill of materials report for conventional precast concrete buildings (CC)

Table 3. Data on activity areas and occupied load.

Table 4. Simulation Inputs on the Building Specifications

Table 5. Simulation Inputs on Roof and Wall specifications 


\section{Results and Discussion}

\subsection{Energy Simulation Results}

The energy simulation is performed on a prototype model using eQUEST 3.64 for two floors office building with total gross area of $26,100 \mathrm{ft}^{2}\left(2424.77 \mathrm{~m}^{2}\right)$. The results show that the peak electricity consumption occurs in July due to high temperatures that cause high energy consumption due to space cooling, equipment, and lighting. Even though July and August record the highest temperatures of the year, they have not shown a big variation in energy consumption because the building is occupied partially during the summer. During winter December and January have slightly high gas consumption due to the fluctuated cold weather that causes high energy consumption for space and water heating, as shown in Figure 4. Moderate and stable gas consumption is recorded during the rest of the year. The lowest electricity consumption is recorded during the winter from November to Mach.

Figure 4: Annual energy consumption for Option 3.

\subsection{LCA Results}

\subsubsection{Total Energy Consumption}

The results of operating energy from the energy simulation process are entered in ATHENA software to measure the total energy consumption and environmental impact of the study building. The total energy consumption of each structure and envelope type in each life cycle 
stage, and the overall energy consumption are summarized in Table 6. It is obvious that precast concrete buildings (CC) have the lowest energy consumption while steel buildings generally show the highest, except for the end-of-life stage. In the steel options, the highest energy consumption for the manufacturing phase is attributed to the high energy consumption during the manufacturing of steel. For the construction stage, all the options except CC show more or less similar trend. This could be interpreted to the fact that the CC involves relatively minimal onsite construction and hence the associated energy use. It is interesting to note that the energy consumption during the maintenance stage for options with double-glazing curtain wall (CG and $\mathrm{SG})$ is the highest while it is the least for the other options. The periodic cleaning requirement for glazed envelope might contribute to higher energy demand during maintenance.

While looking into the end-of-life scenario, CM, CA and SC are the highest, and the other options show the least. This variation could be explained with respect to the energy consumed for demolition, which is obviously lower for buildings made up of prefabricated modules (such as $\mathrm{CC}$ and $\mathrm{SG}$ ) compared with the conventional built-in-site concrete structures (such as $\mathrm{CM}$ ). Similar to the maintenance stage, envelopes with glazed curtain walls (CG and SG) show highest energy consumption in the operating stage as well, while the other options show almost a similar trend. For these options, the excess heat gain due to glazing can increase the cooling load during the operating stage. However, the choice is very clear from the overall energy consumption, which endorses $\mathrm{CC}$ as the best, and regard SG as the worst. Therefore the present lifecycle energy analysis has proved to be effective in deciding the appropriate envelope configuration, based on energy consumption.

Considering the share of energy consumption for each life-cycle stage, the operational or usephase has the highest contribution, which is $88-91 \%$ of the total energy consumption. This is 
consistent with the previous findings of Alshamrani et al. (2014), Junnila et al. (2006), and Cole and Kernan (1996), and the report by Thiel et al. (2013) who stated that buildings ranging from 40 to100 years of life-span showed operational life cycle energy of $80-90 \%$.

Table 6: Energy consumption in life cycle stages

\subsubsection{Global Warming Potential}

The global warming potential (GWP) is expressed as kilograms of $\mathrm{CO}_{2}$ equivalent $\left(\mathrm{kgCO}_{2} \mathrm{e}\right)$, and the GWP of each structure and envelope type in each life cycle stage, and the overall GWP are summarized in Table 7. It is worth noting that operating period of the building is the highest contributor of GWP (88-89\%) in all the cases, followed by the manufacturing stage. The high GWP for the operating stage is consistent with the high energy consumption, because it is well known that the electricity consumption indirectly causes $\mathrm{CO}_{2}$ emission from electricity production, which generates $38 \%$ of the total $\mathrm{CO}_{2}$ according to the latest US environmental protection agency estimates(EPA 2012). Similar argument fits to the GWPs of CC (lowest), and CG and SG (the highest). This will be further clarified in the following section.

Table 7: LCA results for GWP

Figure 5: Comparison of total life cycle GWP for the tested options. 


\subsubsection{Energy Consumption and GWP Distributions}

In order to observe the shares of energy consumption and GWP to major phases of the life cycle, the phases are grouped as manufacture \& construction (building), operation \& maintenance (use) and end-of-life (demolition). The energy consumption and GWP for these phases are averaged regardless of the structure-envelope options, and the percentage shares are estimated and plotted as in Figures 6 and 7 respectively. It is obvious that the GWP is almost proportional to the energy consumption, with highest share for the use phase and the least for demolition phase. This observation is consistent with the previous report on a Greek residential building (Xanthakis 2011), and also substantiates the discussion in the preceding sections on the direct relationship of GWP with the energy consumption.

Figure 6: Energy Consumption of different life cycle stages.

Figure 7: GWP of different life cycle stages.

\subsubsection{Air, Water and Land Emissions}

Table 8 summarizes the air, water and land emissions, which are available as part of the LCA output. Precast concrete buildings contribute the least emissions while steel and concrete buildings with glazing (CG and SG) contribute the highest air emission. Precast buildings use relatively less concrete because of the optimization of materials; fewer materials reduces emissions associated with mining, processing and transporting (VanGeem 2006). The higher air emission in CG and SG can be attributed to the higher energy consumption due to glazing (Table 
6). Also, conventional concrete, steel and glass are good contributors of air emission during their life-cycle stages. For instance, the air emission of concrete it is greatly due to the cement manufacturing, and that in steel manufacturing comprises coke oven gas, naphthalene, ammonium compounds, crude light oil, sulfur and coke dust (www.greenspec.co.uk). The air emissions from glass manufacturing include those from raw materials (the raw materials involved are powdered, granular or dusty), melting (combustion emission, particulate matter and gases from raw materials) and downstream activities such as coating, cutting, polishing, etc. ("Best Available Techniques in the Glass Manufacturing Industry" 2001). In general, the land emission is very nominal compared to water and air emissions. Regarding water emission, the highest contributor is CA, followed by SG and CG. Precast concrete buildings can reduce the water emissions by $44 \%$ over buildings made of CA.

Table 8: LCA results for air, water and land emissions

\subsubsection{Environmental Impact Costs}

Greenhouse gas emissions causing global warming are quantified and then converted to a unified unit equivalent for Carbon Dioxide emissions $\left(\mathrm{CO}_{2}\right.$ e) as shown in Table 9. The current price of environmental impacts is approximately $\$ 30 /$ ton of $\mathrm{CO}_{2}$ (http://www.pointcarbon.com/). Environmental impact costs are added as future costs at the end of building life (60 years). The minimum environmental impact cost is recorded for $\mathrm{CC}$, while the maximum is for a steel building with curtain walls (SG). 
Table 9: Total environmental impacts costs

\section{Conclusion}

The LCA approach has been applied to a typical low-rise office building in New York City and the life cycle energy use and environmental impact are assessed with eight different structureenvelope configurations, based on concrete and steel. The energy simulation is performed by using eQUEST software while the environmental impact is assessed by using ATHENA ${ }^{\circledR}$ impact estimator. The model is applicable for any type of buildings in North America with similar locations and climates (e.g., the Canadian cities such as Vancouver, Victoria and Kamloops have weather conditions almost similar to New York City). This study shows that the structureenvelope configuration should be selected based on the environmental impact assessment of all life cycle stages. Some structure-envelope types show lower energy consumption in early stages such as manufacturing and construction but on the other hand, they contribute high impact over 60 years of operation. For the overall life span, precast concrete buildings show the best performance in terms of energy consumption, global warming potential, and water, air land emissions. The office buildings built by steel or concrete with glazing envelope have high energy consumption and environmental impact. This work can be extended to other types of buildings, climatic conditions, and with different variables.

\section{References}

Alshamrani, Othman Subhi, Khaled Galal, and Sabah Alkass. 2014. "Integrated LCA-LEED Sustainability Assessment Model for Structure and Envelope Systems of School 
Buildings.” Building and Environment 80 (October). Elsevier Ltd: 61-70. doi:10.1016/j.buildenv.2014.05.021.

"Best Available Techniques in the Glass Manufacturing Industry." 2001. Integrated Pollution Prevention and Control (IPPC). European Commission. http://www.prtres.es/data/images/vidrio-052A143B3A73F757.pdf.

Cabeza, Luisa F., Lídia Rincón, Virginia Vilariño, Gabriel Pérez, and Albert Castell. 2014. “Life Cycle Assessment (LCA) and Life Cycle Energy Analysis (LCEA) of Buildings and the Building Sector: A Review." Renewable and Sustainable Energy Reviews 29 (January): 394-416. doi:10.1016/j.rser.2013.08.037.

Cole, Raymond J. 1998. "Emerging Trends in Building Environmental Assessment Methods." Building Research \& Information $26 \quad$ (February 2015): 3-16. doi:10.1080/096132198370065.

Cole, Raymond J., and Paul C. Kernan. 1996. "Life-Cycle Energy Use in Office Buildings." Building and Environment 31 (4): 307-17. doi:10.1016/0360-1323(96)00017-0.

Collinge, William, Amy E. Landis, Alex K. Jones, Laura a. Schaefer, and Melissa M. Bilec. 2013. “Indoor Environmental Quality in a Dynamic Life Cycle Assessment Framework for Whole Buildings: Focus on Human Health Chemical Impacts.” Building and Environment 62. Elsevier Ltd: 182-90. doi:10.1016/j.buildenv.2013.01.015.

Collinge, William O., Amy E. Landis, Alex K. Jones, Laura a. Schaefer, and Melissa M. Bilec. 2013. "Dynamic Life Cycle Assessment: Framework and Application to an Institutional Building." The International Journal of Life Cycle Assessment 18: 538-52. doi:10.1007/s11367-012-0528-2. 
Ding, Grace K. C. 2007. "Life Cycle Energy Assessment of Australian Secondary Schools." Building Research \& Information 35 (February 2015): 487-500. doi:10.1080/09613210601116408.

DOE. 2015. "Buildings Energy Data Book." US Department of Energy. http://bhttp//buildingsdatabook.eren.doe.gov/TableView. aspx?table=1.1.3uildingsdataboo k.eren.doe.gov/TableView .aspx?table=1.1.3.

EPA. 2012. "Carbon Dioxide Emissions." US Environmental Protection Agency. http://www.epa.gov/climatechange/ghgemissions/gases/co2.html.

Frenette, Caroline D., Cécile Bulle, Robert Beauregard, Alexander Salenikovich, and Dominique Derome. 2010. "Using Life Cycle Assessment to Derive an Environmental Index for Light-Frame Wood Wall Assemblies." Building and Environment 45 (10): 2111-22. doi:10.1016/j.buildenv.2010.03.009.

Grant, Aneurin, and Robert Ries. 2012. "Impact of Building Service Life Models on Life Cycle Assessment." Building Research \& Information, no. February 2015: 168-86. doi: $10.1080 / 09613218.2012 .730735$.

Hernandez, Patxi, and Paul Kenny. 2010. "Integrating Occupant Preference and Life Cycle Energy Evaluation: A Simplified Method." Building Research \& Information 38 (6): 625-37. doi:10.1080/09613218.2010.513209.

Iwaro, J, A Mwasha, R G Williams, and W Wilson. 2014. "The Role of Integrated Performance Model in Sustainable Envelope Design and Assessment." International Journal of Sustainable Engineering, 37-41. doi:10.1080/19397038.2014.930211. 
Junnila, Seppo, Arpad Horvath, and Angela Acree Guggemos. 2006. "Life-Cycle Assessment of Office Buildings in Europe and the United States." Journal of Infrastructure Systems 12 (1): 10-17. doi:10.1061/(ASCE)1076-0342(2006)12:1(10).

Khasreen, Mohamad Monkiz, Phillip F G Banfill, and Gillian F. Menzies. 2009. "Life-Cycle Assessment and the Environmental Impact of Buildings: A Review." Sustainability 1: 674-701. doi:10.3390/su1030674.

König, Holger, and M. Lisa De Cristofaro. 2012. "Benchmarks for Life Cycle Costs and Life Cycle Assessment of Residential Buildings.” Building Research \& Information 40 (5): 558-80. doi:10.1080/09613218.2012.702017.

Liu, Meng, Baizhan Li, and Runming Yao. 2010. “A Generic Model of Exergy Assessment for the Environmental Impact of Building Lifecycle." Energy and Buildings 42 (9). Elsevier B.V.: 1482-90. doi:10.1016/j.enbuild.2010.03.018.

Mora, Rodrigo, Girma Bitsuamlak, and Miljana Horvat. 2011. "Integrated Life-Cycle Design of Building Enclosures." Building and Environment 46 (7). Elsevier Ltd: 1469-79. doi:10.1016/j.buildenv.2011.01.018.

Onat, Nuri Cihat, Murat Kucukvar, and Omer Tatari. 2014. "Scope-Based Carbon Footprint Analysis of U.S. Residential and Commercial Buildings: An Input-Output Hybrid Life Cycle Assessment Approach." Building and Environment 72. Elsevier Ltd: 53-62. doi:10.1016/j.buildenv.2013.10.009.

Ortiz, Oscar, Francesc Castells, and Guido Sonnemann. 2009. "Sustainability in the Construction Industry: A Review of Recent Developments Based on LCA." Construction 
and Building Materials 23 (1). Elsevier Ltd: 28-39. doi:10.1016/j.conbuildmat.2007.11.012.

Pons, Oriol, and Albert De La Fuente. 2013. "Integrated Sustainability Assessment Method Applied to Structural Concrete Columns." Construction and Building Materials 49. Elsevier Ltd: 882-93. doi:10.1016/j.conbuildmat.2013.09.009.

Proietti, Stefania, Paolo Sdringola, Umberto Desideri, Francesco Zepparelli, Francesco Masciarelli, and Francesco Castellani. 2013. "Life Cycle Assessment of a Passive House in a Seismic Temperate Zone." Energy and Buildings 64. Elsevier B.V.: 463-72. doi:10.1016/j.enbuild.2013.05.013.

Ramesh, T., Ravi Prakash, and K.K. Shukla. 2010. "Life Cycle Energy Analysis of Buildings: An Overview." Energy and Buildings $42 \quad$ (10): 1592-1600. doi:10.1016/j.enbuild.2010.05.007.

Reza, Bahareh, Rehan Sadiq, and Kasun Hewage. 2011. "Sustainability Assessment of Flooring Systems in the City of Tehran: An AHP-Based Life Cycle Analysis." Construction and Building Materials $25 \quad$ (4): 2053-66. doi:10.1016/j.conbuildmat.2010.11.041.

Sharma, Aashish, Abhishek Saxena, Muneesh Sethi, and Venu Shree. 2011. "Life Cycle Assessment of Buildings: A Review." Renewable and Sustainable Energy Reviews 15 (1). Elsevier Ltd: 871-75. doi:10.1016/j.rser.2010.09.008.

Thiel, Cassandra L., Nicole Campion, Amy E. Landis, Alex K. Jones, Laura a. Schaefer, and Melissa M. Bilec. 2013. “A Materials Life Cycle Assessment of a Net-Zero Energy Building.” Energies 6: 1125-41. doi:10.3390/en6021125. 
Thormark, Catarina. 2000. "Including Recycling Potential in Energy Use into the Life-Cycle of Buildings.” Building Research \& Information $28 \quad$ (3): 176-83. doi:10.1080/096132100368948.

Treloar, G., R. Fay, P. E. D. Love, and U. Iyer-Raniga. 2000. “Analysing the Life-Cycle Energy of an Australian Residential Building and Its Householders." Building Research \& Information 28 (3): 184-95. doi:10.1080/096132100368957.

VanGeem, Martha. 2006. “Achieving Sustainability with Precast Concrete.” PCI Journal, no. Jan-Feb: 42-61. doi:10.15554/pcij.01012006.42.61.

Wang, Nannan, Yen-Chiang Chang, and Chris Nunn. 2010. "Lifecycle Assessment for Sustainable Design Options of a Commercial Building in Shanghai." Building and Environment 45 (6). Elsevier Ltd: 1415-21. doi:10.1016/j.buildenv.2009.12.004.

Xanthakis, G J. 2011. "Life Cycle Assessment of Buildings. The Case of a Dwelling in Greece." In Proceedings of the 3rd International CEMEPE \& SECOTOX Conference Skiathos, June 19-24, 2011, ISBN 978-960-6865-43-5., 1165-70.

Xing, Su, Zhang Xu, and Gao Jun. 2008. "Inventory Analysis of LCA on Steel- and ConcreteConstruction Office Buildings." Energy and Buildings 40 (7): 1188-93. doi:10.1016/j.enbuild.2007.10.016.

Zhang, Zhihui, Xing Wu, Xiaomin Yang, and Yimin Zhu. 2006. "BEPAS - A Life Cycle Building Environmental Performance Assessment Model.” Building and Environment 41: 669-75. doi:10.1016/j.buildenv.2005.02.028. 
Table1: Tested Structure-Envelope configurations with floor and roof types.

\begin{tabular}{|c|c|c|c|c|c|c|}
\hline \multicolumn{3}{|c|}{ Options } & Frame Type & Exterior Walls & Floor Type & Roof Type \\
\hline 1 & \multirow{4}{*}{ 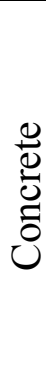 } & $\mathrm{CC}$ & $\begin{array}{l}\text { Precast } \\
\text { concrete }\end{array}$ & Precast concrete & Hollow core slab & $\begin{array}{l}\text { Hollow core } \\
\text { slab }\end{array}$ \\
\hline 2 & & $\mathrm{CM}$ & Concrete & $\begin{array}{l}\text { Face brick with } \\
\text { concrete block }\end{array}$ & $\begin{array}{c}\text { Solid concrete } \\
\text { slab }\end{array}$ & $\begin{array}{c}\text { Solid concrete } \\
\text { slab }\end{array}$ \\
\hline 3 & & $\mathrm{CA}$ & Concrete & $\begin{array}{l}\text { Aluminium } \\
\text { cladding }\end{array}$ & $\begin{array}{c}\text { Solid concrete } \\
\text { slab }\end{array}$ & $\begin{array}{l}\text { Solid concrete } \\
\text { slab }\end{array}$ \\
\hline 4 & & CG & Concrete & $\begin{array}{l}\text { Double-glazed } \\
\text { curtain walls }\end{array}$ & $\begin{array}{c}\text { Solid concrete } \\
\text { slab }\end{array}$ & $\begin{array}{l}\text { Solid concrete } \\
\text { slab }\end{array}$ \\
\hline 5 & \multirow{4}{*}{$\stackrel{\bar{\Phi}}{\text { D }}$} & SS & Steel & $\begin{array}{l}\text { Steel siding on } \\
\text { steel studs }\end{array}$ & $\begin{array}{l}\text { Concrete/metal } \\
\text { deck/open joists }\end{array}$ & $\begin{array}{l}\text { Metal deck on } \\
\text { open web joists }\end{array}$ \\
\hline 6 & & $\mathrm{SC}$ & Steel & $\begin{array}{l}\text { Face brick with } \\
\text { steel studs }\end{array}$ & $\begin{array}{l}\text { Concrete/metal } \\
\text { deck/open joists }\end{array}$ & $\begin{array}{l}\text { Metal deck on } \\
\text { open web joists }\end{array}$ \\
\hline 7 & & SA & Steel & $\begin{array}{l}\text { Aluminium } \\
\text { cladding }\end{array}$ & $\begin{array}{l}\text { Concrete/metal } \\
\text { deck/open joists }\end{array}$ & $\begin{array}{l}\text { Metal deck on } \\
\text { open web joists }\end{array}$ \\
\hline 8 & & SG & Steel & $\begin{array}{l}\text { Double-glazed } \\
\text { curtain walls }\end{array}$ & $\begin{array}{l}\text { Concrete/metal } \\
\text { deck/open joists }\end{array}$ & $\begin{array}{l}\text { Metal deck on } \\
\text { open web joists }\end{array}$ \\
\hline
\end{tabular}


Table 2: Bill of materials report for conventional precast concrete buildings (CC)

\begin{tabular}{|l|l|l|}
\hline \multicolumn{1}{|c|}{ Material } & \multicolumn{1}{c|}{ Quantity } & \multicolumn{1}{c|}{ Unit } \\
\hline 1/2" Gypsum Fibre Gypsum Board & 343.2 & $\mathrm{~m}^{2}$ \\
\hline 3 mil Polyethylene & 2040 & $\mathrm{~m}^{2}$ \\
\hline Aluminum & 0.5 & Tonnes \\
\hline Batt. Fiberglass & 2275.35 & $\mathrm{~m}^{2}(25 \mathrm{~mm})$ \\
\hline Batt. Rockwool & 2275.35 & $\mathrm{~m}^{2}(25 \mathrm{~mm})$ \\
\hline Clay Tile & 7062 & $\mathrm{~m}^{2}$ \\
\hline Concrete 20 MPa (flyash av) & 326.55 & $\mathrm{~m}^{3}$ \\
\hline Concrete 30 MPa (flyash av) & 894.6 & $\mathrm{~m}^{3}$ \\
\hline Concrete 60 MPa (flyash av) & 229.4342 & $\mathrm{~m}^{3}$ \\
\hline Concrete Blocks & 19089 & Blocks \\
\hline Galvanized Decking & 0.505 & Tonnes \\
\hline Low E Silver Argon Filled Glazing & 2020 & $\mathrm{~m}^{2}$ \\
\hline Mortar & 60.6303 & $\mathrm{~m}^{3}$ \\
\hline PVC membrane & 13209.75 & $\mathrm{~kg}$ \\
\hline Rebar, Rod, Light Sections & 114.1835 & Tonnes \\
\hline Small Dimension Softwood Lumber, Green & 2883.6 & $\mathrm{~m}^{3}$ \\
\hline Welded Wire Mesh / Ladder Wire & 12.1793 & Tonnes \\
\hline
\end{tabular}


Table 3. Data on activity areas and occupied load.

\begin{tabular}{|c|c|c|c|c|c|c|}
\hline \multirow[b]{2}{*}{ Space Type } & \multicolumn{4}{|c|}{ Activity Areas Allocation } & \multicolumn{2}{|c|}{ Occupied Loads } \\
\hline & $\begin{array}{c}\text { Total } \\
\text { Area } \\
\left(\mathbf{f t}^{2}\right) \\
\end{array}$ & $\begin{array}{l}\% \text { of } \\
\text { Area }\end{array}$ & $\begin{array}{c}\text { Design Max } \\
\text { occupancy } \\
\left(\mathrm{ft}^{2} / \text { person) }\right.\end{array}$ & $\begin{array}{c}\text { Design } \\
\text { Ventilation } \\
\text { (cfm/person) } \\
\end{array}$ & $\begin{array}{l}\text { Lighting } \\
\left(\mathbf{w} / \mathbf{f t}^{2}\right)\end{array}$ & $\begin{array}{r}\text { Plug } \\
\text { loads } \\
\left(\mathbf{w} / \mathbf{f t}^{2}\right) \\
\end{array}$ \\
\hline Offices & 18270 & $70 \%$ & 225 & 20 & 1.3 & 1.5 \\
\hline Corridors & 2610 & $10 \%$ & 150 & 7.5 & 0.6 & 0.2 \\
\hline Lobby & 1305 & $5.0 \%$ & 150 & 15.0 & 1.1 & 0.5 \\
\hline Restrooms & 1305 & $5.0 \%$ & 52.5 & 50.0 & 0.6 & 0.2 \\
\hline Conference Room & 1044 & $4.0 \%$ & 22.5 & 20.0 & 1.6 & 1.0 \\
\hline $\begin{array}{c}\text { Mechanical/Elect. } \\
\text { Room }\end{array}$ & 1044 & $4.0 \%$ & 450 & 22.5 & 0.7 & 0.2 \\
\hline Copy Room & 522 & $2.0 \%$ & 187 & 93.75 & 1.5 & 3.0 \\
\hline Total & 26,100 & $100 \%$ & & & & \\
\hline
\end{tabular}


Table 4. Simulation Inputs on the Building Specifications

\begin{tabular}{|l|l|}
\hline Item & Specification \\
\hline Building type & Low-rise office building \\
\hline Total gross area & $26,100 \mathrm{ft}^{2}$ \\
\hline No. of floors & $2 \mathrm{floor}$ \\
\hline Number of students & 120 \\
\hline Building orientation & Long Axis oriented (North-South) \\
\hline Floor height & $12.0 \mathrm{ft}$ \\
\hline Floor to ceiling height & $9.0 \mathrm{ft}$ \\
\hline Windows area & $40 \%$ fenestration to gross wall area \\
\hline Glazing sill height & $3.0 \mathrm{ft}$ \\
\hline Plan configuration & Rectangular- shape \\
\hline Location (city) & New York, USA \\
\hline Climate zone & $4 \mathrm{a}($ Mixed $-\mathrm{Humid})$ \\
\hline Percent conditioned & Fully heated and cooled \\
\hline Thermal transmittance of window & $\mathrm{U}-(0.959)\left(\mathrm{btu} / \mathrm{h}-\mathrm{ft}-{ }^{\circ} \mathrm{F}\right)$ \\
\hline Solar heat gain coefficient & $\left(\right.$ SHGC)-0.40 $\left(\mathrm{btu} / \mathrm{h}-\mathrm{ft}-{ }^{\circ} \mathrm{F}\right)$ \\
\hline $\begin{array}{l}\text { Infiltration Ext } \\
\text { (perimeter) }\end{array}$ & $0.038 \mathrm{CFM} / \mathrm{ft}{ }^{2}$ \\
\hline Infiltration floor area (core) & $0.001 \mathrm{CFM} / \mathrm{ft}{ }^{2}$ \\
\hline Heating equipment & Hot water coils \\
\hline Cooling equipment & Chilled water coils \\
\hline Analysis year & 2013 \\
\hline Code & ASHRAE 90.1, ASHRAE 62 \\
\hline
\end{tabular}


Table 5. Simulation Inputs on Roof and Wall specifications

\begin{tabular}{|c|c|c|c|c|c|}
\hline No. & Type & $\begin{array}{l}\text { Thickness } \\
(\mathbf{m m})\end{array}$ & $\begin{array}{l}\text { Insulation } \\
\text { Type }\end{array}$ & $\begin{array}{c}\text { Total } \\
\text { Thickness } \\
(\mathbf{m m})\end{array}$ & $\begin{array}{c}\text { U- value } \\
\text { (btu/h-ft- } \\
\left.{ }^{\circ} \mathrm{F}\right)\end{array}$ \\
\hline \multicolumn{6}{|c|}{ Roof } \\
\hline 1 & Solid concrete slab & 150 & \multirow{3}{*}{$\begin{array}{c}\text { Board Insulation } \\
\text { (polystyrene, } \\
\text { Expanded,3 Inch } \\
\text { (IN36); } \\
\text { U-value }=0.020 \mathrm{btu} / \mathrm{h}- \\
\left.\mathrm{ft}-{ }^{\circ} \mathrm{F}\right)\end{array}$} & 240 & 0.055 \\
\hline 2 & Hollow- core slab & 150 & & 240 & 0.050 \\
\hline 3 & Metal deck- steel joist & 75 & & 150 & 0.076 \\
\hline \multicolumn{6}{|c|}{ Wall } \\
\hline 1 & Pre cast wall & 200 & \multirow{4}{*}{$\begin{array}{c}\text { Board Insulation } \\
\text { (Preformed mineral } \\
\text { board , } 2 \text { Inch (IN23) } \\
\mathrm{U}(0.024) \\
\left(\mathrm{btu} / \mathrm{h}-\mathrm{ft}-{ }^{\circ} \mathrm{F}\right)\end{array}$} & 257 & 0.073 \\
\hline 2 & Masonry (Cavity Wall) & 250 & & 307 & 0.098 \\
\hline 3 & Aluminium cladding & 107 & & 107 & 0.142 \\
\hline 4 & $\begin{array}{l}\text { Double Glazed Curtain } \\
\text { Wall }\end{array}$ & 107 & & 107 & 0.0959 \\
\hline
\end{tabular}


Table 6: Energy consumption in life cycle stages

\begin{tabular}{|c|c|c|c|c|c|c|c|}
\hline \multirow{2}{*}{\multicolumn{2}{|c|}{$\begin{array}{l}\text { Structure - } \\
\text { Envelope } \\
\text { Alternatives }\end{array}$}} & \multicolumn{5}{|c|}{ Total Energy Consumption in Life-Cycle Stages $\left(\mathrm{kWh} \times 10^{6}\right)$} & \multirow{2}{*}{$\begin{array}{c}\text { Overall } \\
\left(\mathrm{kWh} \times 10^{6}\right)\end{array}$} \\
\hline & & Manufacture & Construction & Maintenance & End-of-Life & Operating & \\
\hline \multirow{4}{*}{ 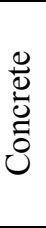 } & $\mathrm{CC}$ & 3.25 & 0.144 & 0.763 & 0.945 & 52.93 & 58.03 \\
\hline & $\mathrm{CM}$ & 3.56 & 0.208 & 0.763 & 1.367 & 53.50 & 59.40 \\
\hline & $\mathrm{CA}$ & 3.69 & 0.203 & 1.054 & 1.363 & 53.73 & 60.04 \\
\hline & $\mathrm{CG}$ & 3.60 & 0.193 & 1.186 & 0.953 & 56.12 & 62.05 \\
\hline \multirow{4}{*}{$\begin{array}{l}\bar{\Xi} \\
\stackrel{\Delta}{\tilde{D}}\end{array}$} & SS & 4.81 & 0.211 & 0.763 & 0.943 & 54.53 & 61.25 \\
\hline & $\mathrm{SC}$ & 4.85 & 0.213 & 0.763 & 1.350 & 53.99 & 61.16 \\
\hline & SA & 5.00 & 0.208 & 0.763 & 0.943 & 54.51 & 61.41 \\
\hline & SG & 4.78 & 0.207 & 1.187 & 0.941 & 56.26 & 63.38 \\
\hline
\end{tabular}


Table 7: LCA results for GWP

\begin{tabular}{|c|c|c|c|c|c|c|}
\hline \multirow{2}{*}{$\begin{array}{l}\text { Structure- } \\
\text { Envelope } \\
\text { Options }\end{array}$} & \multicolumn{5}{|c|}{ Total GWP during life cycle stages $\left(\mathrm{kgCO}_{2} \mathrm{e}\right)$} & \multirow{2}{*}{$\begin{array}{l}\text { Overall GWP } \\
\qquad\left(\mathrm{kgCO}_{2} \mathrm{e}\right)\end{array}$} \\
\hline & Manufacture & Construction & Operating & Maintenance & End-of-Life & \\
\hline $\mathrm{CC}$ & 1077000 & 7000 & 13179000 & 187000 & 210000 & 14660000 \\
\hline $\mathrm{CM}$ & 1148000 & 16000 & 13322000 & 186900 & 307000 & 14979900 \\
\hline CA & 1178000 & 15500 & 13379000 & 265000 & 307000 & 15144500 \\
\hline CG & 1182000 & 14500 & 13972000 & 418000 & 211000 & 15797500 \\
\hline $\mathrm{SS}$ & 1234000 & 6800 & 13576000 & 187000 & 212000 & 15215800 \\
\hline $\mathrm{SC}$ & 1257000 & 7300 & 13442000 & 186900 & 306000 & 15199200 \\
\hline SA & 1278000 & 6800 & 13572000 & 187000 & 211000 & 15254800 \\
\hline SG & 1270000 & 6400 & 14006000 & 418000 & 210800 & 15911200 \\
\hline
\end{tabular}


Table 8: LCA results for air, water and land emissions

\begin{tabular}{|c|c|c|c|}
\hline Options & \multicolumn{3}{|c|}{ Emission Index $\times 10^{8}$} \\
\hline & Air & Water & Land \\
\hline CC & 1.75 & 5400 & 0.0142 \\
\hline CM & 1.79 & 5620 & 0.0151 \\
\hline CA & 1.81 & 9710 & 0.0153 \\
\hline CG & 1.97 & 5990 & 0.0159 \\
\hline SS & 1.81 & 5770 & 0.0147 \\
\hline SC & 1.81 & 5840 & 0.0148 \\
\hline SA & 1.86 & 5870 & 0.0150 \\
\hline SG & 1.96 & 6120 & 0.0153 \\
\hline
\end{tabular}


Table 9: Total environmental impacts costs

\begin{tabular}{|c|c|c|}
\hline Options & $\begin{array}{c}\text { Env. Impact } \\
\left.\text { (Tons of } \mathrm{CO}_{2} \mathrm{e}\right)\end{array}$ & $\begin{array}{c}\text { Env. Impact Cost } \\
\text { (USD) }\end{array}$ \\
\hline $\mathrm{CC}$ & 14660 & $\$ 439800$ \\
\hline $\mathrm{CM}$ & 14979.9 & $\$ 449397$ \\
\hline $\mathrm{CA}$ & 15144.5 & $\$ 454335$ \\
\hline $\mathrm{CG}$ & 15797.5 & $\$ 473925$ \\
\hline $\mathrm{SS}$ & 15215.8 & $\$ 456474$ \\
\hline $\mathrm{SC}$ & 15199.2 & $\$ 455976$ \\
\hline $\mathrm{SA}$ & 15254.8 & $\$ 457644$ \\
\hline $\mathrm{SG}$ & 15911.2 & $\$ 477336$ \\
\hline
\end{tabular}




\section{Figure Captions}

Figure 1: The proposed environmental impact assessment model.

Figure 2: Detailed sections for structure-envelope options such as CC, CM, SC and SS.

Figure 3: Structural framing plan and 3D perspective for the prototype tested model:

a) Structural plan, b) Perspective view.

Figure 4: Annual energy consumption for Option 3.

Figure 5: Comparison of total life cycle GWP for the tested options.

Figure 6: Energy Consumption of different life cycle stages.

Figure 7: GWP of different life cycle stages. 


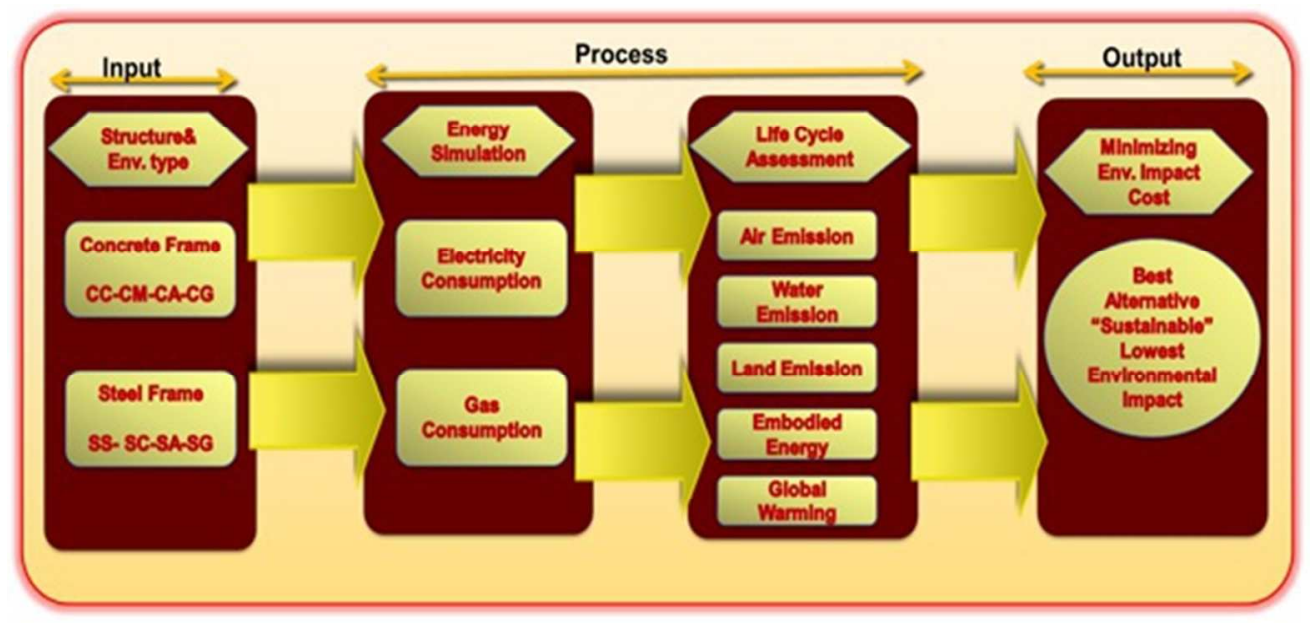

Figure 1: The proposed environmental impact assessment model. $126 \times 59 \mathrm{~mm}(120 \times 120 \mathrm{DPI})$ 

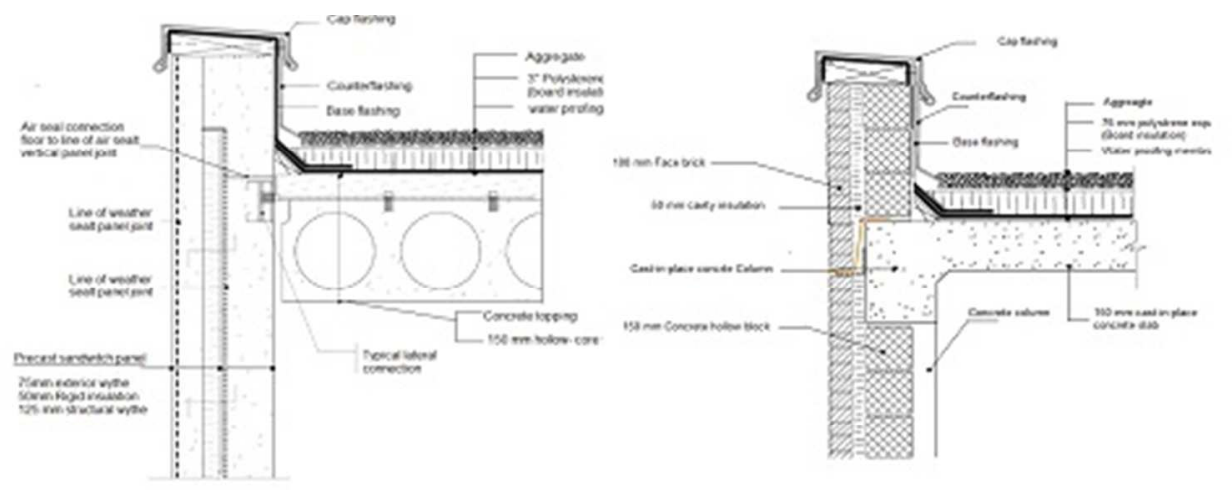

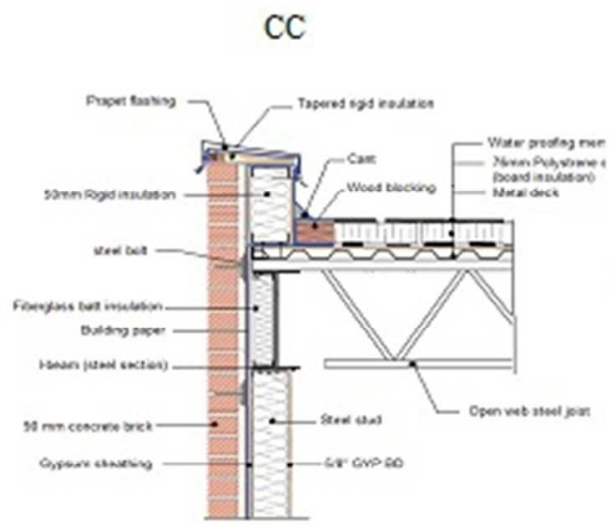

SC

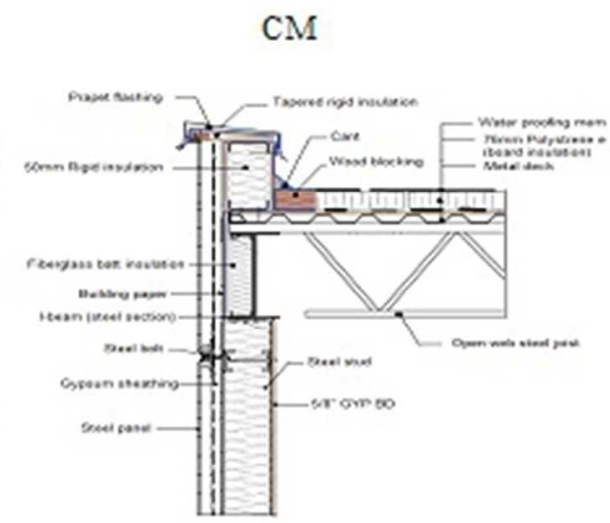

SS

Figure 2: Detailed sections for structure-envelope options such as CC, CM, SC and SS. $105 \times 99 \mathrm{~mm}(120 \times 120 \mathrm{DPI})$ 


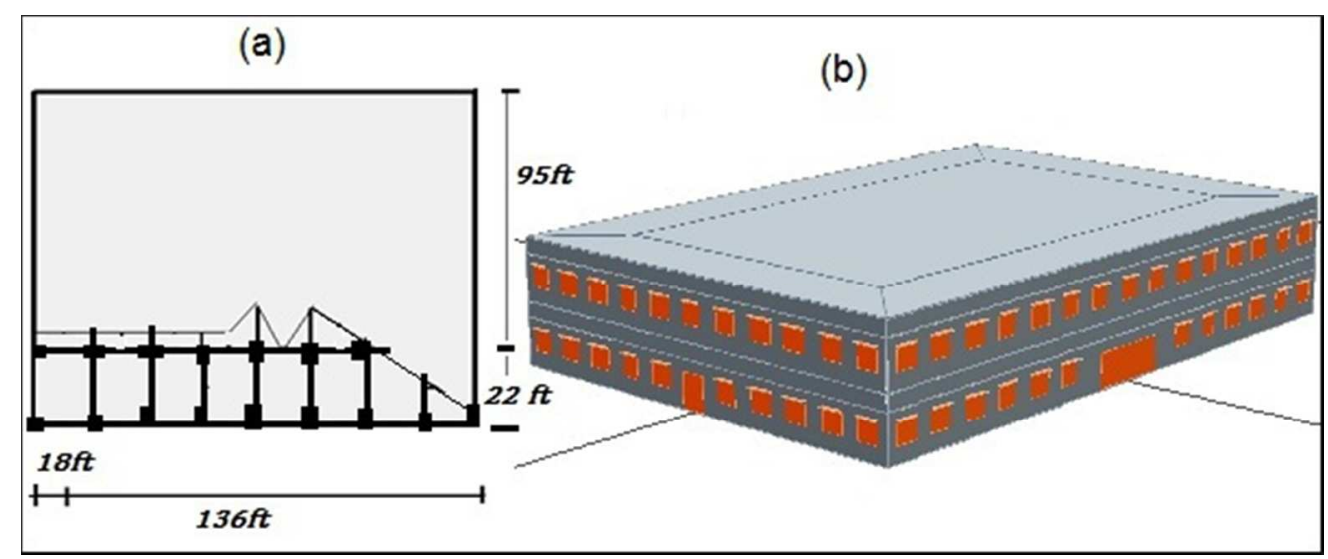

Figure 3: Structural framing plan and 3D perspective for the prototype tested model: a) Structural plan, b) Perspective view.

$126 \times 52 \mathrm{~mm}(120 \times 120$ DPI $)$ 


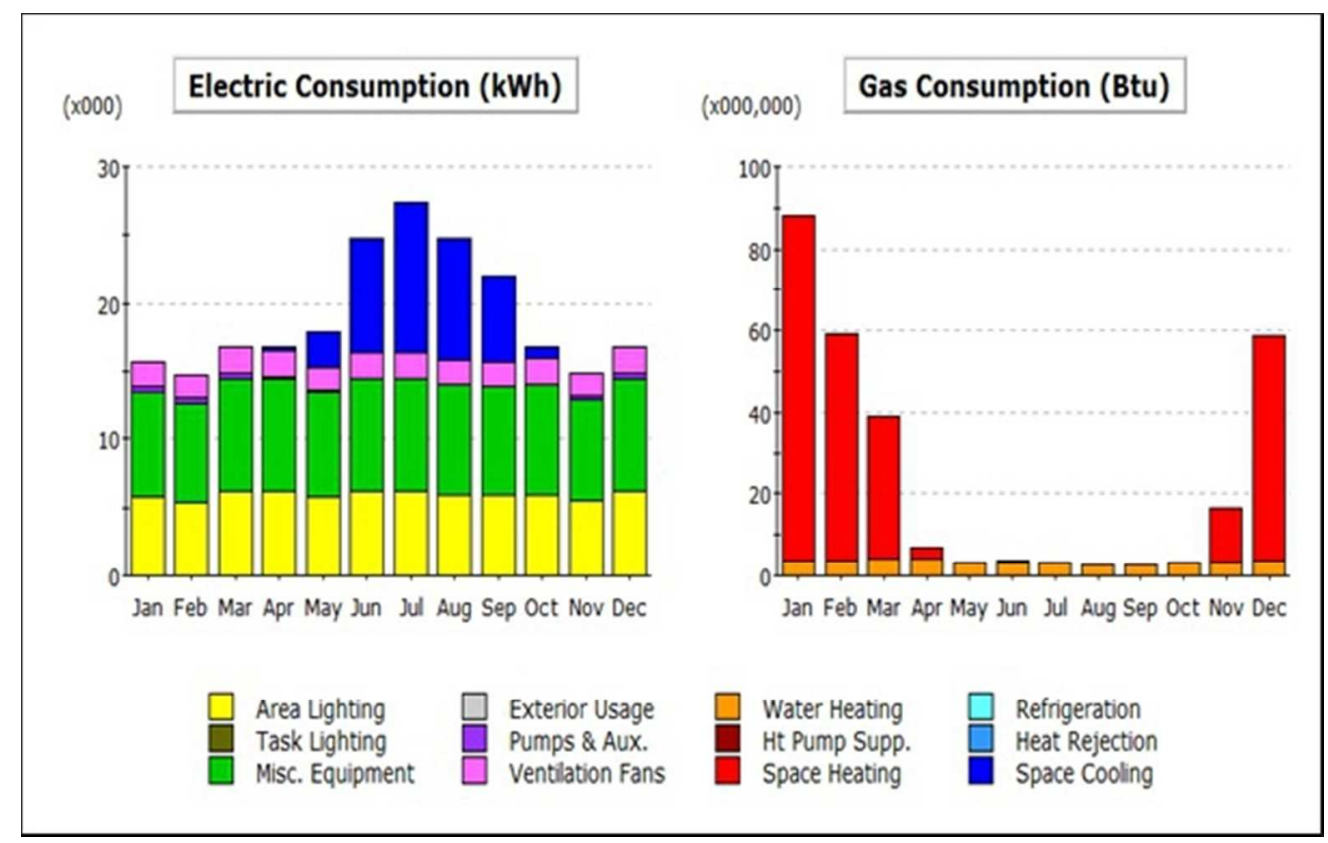

Figure 4: Annual energy consumption for Option 3. $127 \times 80 \mathrm{~mm}(120 \times 120 \mathrm{DPI})$ 


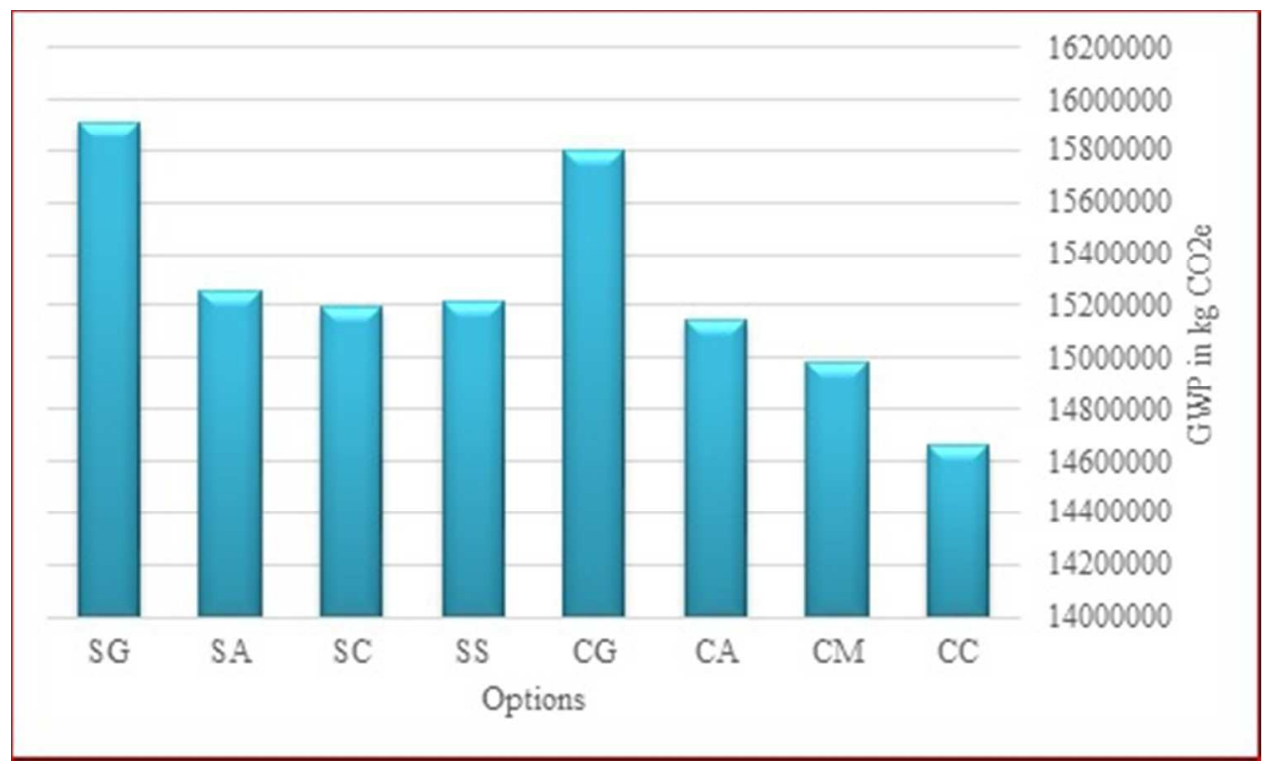

Figure 5: Comparison of total life cycle GWP for the tested options. $101 \times 60 \mathrm{~mm}(120 \times 120 \mathrm{DPI})$ 


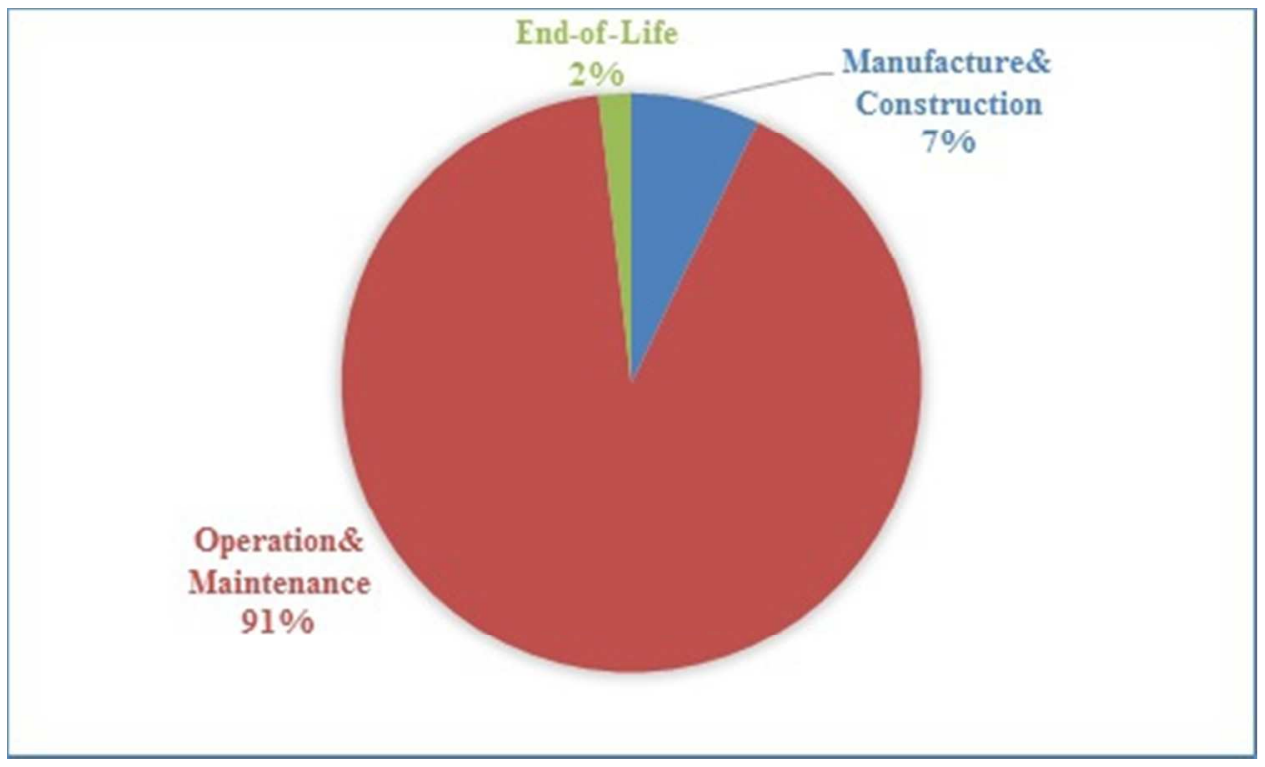

Figure 6: Energy Consumption of different life cycle stages. $101 \times 60 \mathrm{~mm}(120 \times 120 \mathrm{DPI})$ 


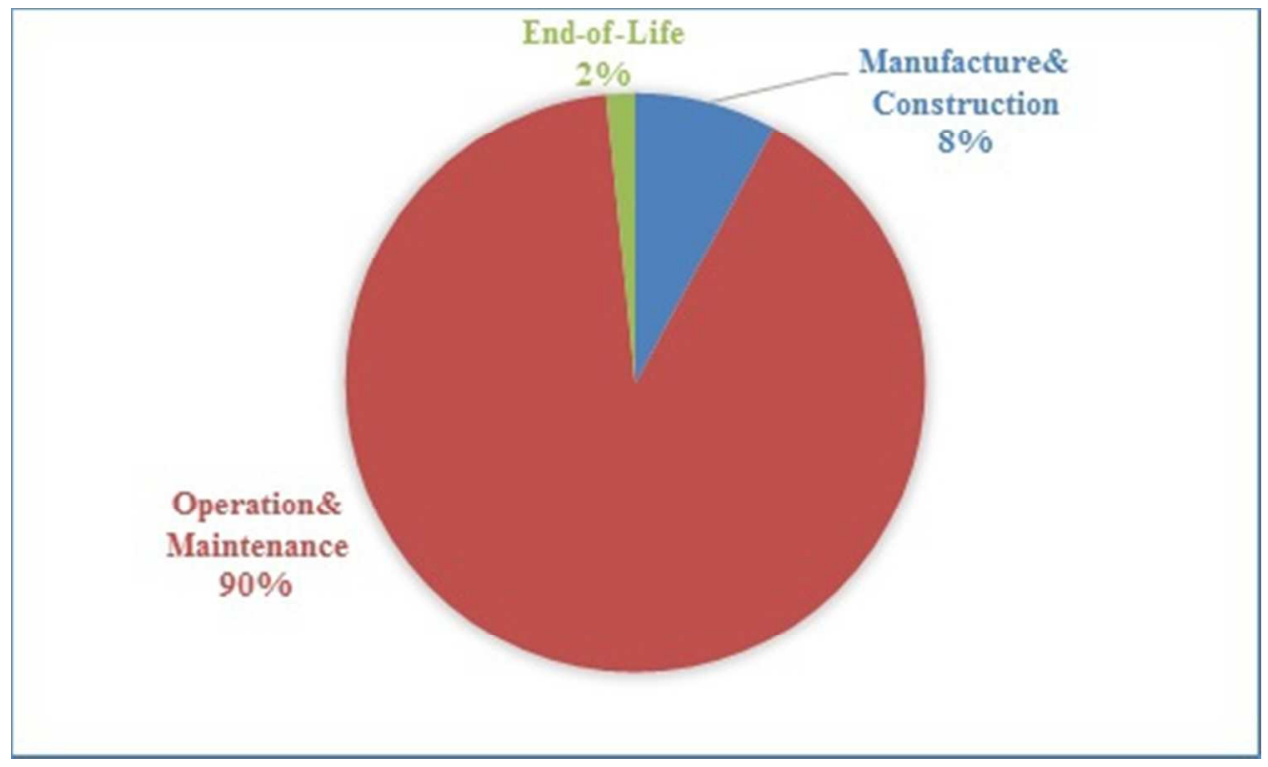

Figure 7: GWP of different life cycle stages. $101 \times 60 \mathrm{~mm}(120 \times 120 \mathrm{DPI})$ 